\title{
Best-Practice Guideline on the Prevention of Abuse and Neglect of Older Adults*
}

\author{
Sandra P. Hirst, ${ }^{1}$ Tasha Penney, ${ }^{2}$ Susan McNeill, ${ }^{2}$ Veronique M. Boscart, ${ }^{3}$ Elizabeth Podnieks, ${ }^{4}$ \\ and Samir K. Sinha
}

\begin{abstract}
RÉSUMÉ
Une revue systématique de la littérature a été effectuée afin d'identifier des moyens efficaces pour prévenir et combattre l'abus et la négligence envers les adultes âgés dans les établissements de soins de santé au Canada. L'examen a été fait en utilisant les bases de données qui ont été recherchés à partir de janvier 2000 à avril / mai 2013. En outre, les membres des groupes d'experts ont présenté les citations d'articles tirés des archives personnelles. Deux associés de recherche infirmier (ARI) ont selectionné chaque titre et chaque résumé pour l'inclusion. Après le coefficient d'objectivité a été déterminé entre les ARI (score Kappa de 0,76), les dossiers ont été divisés, évalués et les données extraites indépendamment. L'examen a révélé 62 études portant sur l'identification, l'évaluation et la réponse à l'abus et la négligence des personnes âgées; stratégies d'éducation, de prévention et de promotion de la santé; et soutien organisationnel au niveau du système pour prévenir et combattre ce type de maltraitance et de négligence. L'abus et la négligence envers les aînés demeure peu exploré en termes d'études fondées sur des preuves; par conséquent, il faut davantage de recherche dans tous les domaines décrites.
\end{abstract}

\begin{abstract}
A systematic review of the literature was conducted to identify effective approaches to preventing and addressing abuse and neglect of older adults within health care settings in Canada. The review was conducted using databases searched from January 2000-April-May 2013. Additionally, expert panel members submitted article citations from personal archives. Two research associates (NRA) screened each title and abstract for inclusion. After inter-rater reliability was determined between the NRAs (Kappa score of 0.76), the records were divided, appraised, and data extracted independently. The review resulted in 62 studies that focused on identifying, assessing, and responding to abuse and neglect of older adults; education, prevention, and health promotion strategies; and organizational and system-level supports to prevent and respond to abuse and neglect. Abuse and neglect of older adults remains under-explored in terms of evidence-based studies; consequently, further research in all of the areas described in the results is needed.
\end{abstract}

1 University of Calgary - Faculty of Nursing

2 Registered Nurses' Association of Ontario

3 Conestoga College Institute of Technology and Advanced Learning

4 Ryerson University

5 Mt. Sinai Hospital, Toronto

* Funded by the Government of Canada's New Horizons for Seniors Program. Conflicts of Interest: There are no identified conflicts of interest for the research team and authors. The opinions and interpretations in this publication are those of the authors and do not necessarily reflect those of the Government of Canada.

Manuscript received: / manuscrit reçu : 23/02/15

Manuscript accepted: / manuscrit accepté : 23/08/15

Mots clés : vieillissement, l'abus (maltraitance), négligence, meilleurs pratiques, aînés

Keywords: aging, abuse, neglect, best practices, seniors

La correspondance et les demandes de tirés-à-part doivent être adressées à : / Correspondence and requests for offprints should be sent to:

Sandra P. Hirst, R.N., Ph.D., GNC(C)

University of Calgary

Faculty of Nursing

25 University Dr. NW

Calgary, AB T2N 1N4

(shirst@ucalgary.ca) 


\section{Background}

The past few decades have seen a substantial increase in the awareness and understanding, and the personal and societal costs, related to the abuse and neglect of older adults in Canadian society. Supporting this has been substantial growth in research studies, specific to the incidence, prevalence, causation, and detection of abuse and neglect of older adults. In Canada, it is currently estimated that the prevalence of abuse and neglect ranges from between 4 and 10 per cent among those aged 65 and older, although some researchers believe this may still underestimate an often hidden issue within our society (Brennan, 2009; Canadian Centre for Justice Statistics, 2002; Podnieks, Pillemer, Nicholson, Shillington, \& Frizze, 1990; Pottie-Bunge, 2000).

The World Health Organization (WHO) (2000a, 2000b) has been influential in establishing a commonly used definition of abuse: "a single, or repeated act, or lack of appropriate action, occurring within any relationship where there is an expectation of trust which causes harm or distress to an older person" (p. 126). The United Nations International Plan of Action (2002) adopted in Madrid recognized the importance of addressing abuse and neglect of older adults and incorporated it within its framework for universal human rights.

Authorities or key stakeholder organizations in every Canadian jurisdiction, with the exception of Nunavut, have adopted a definition of abuse and neglect of older adults. The National Seniors Council of Canada (2007) identified that abuse may take numerous forms: financial, physical, emotional or psychological, sexual, systemic, spiritual, and neglect. Subsequently, the National Initiative for the Care of the Elderly (2012) in Canada developed through consensus building the following definition, "Mistreatment of older adults refers to actions/behaviours or lack of actions/behaviours that cause harm or risk of harm within a trust relationship" (McDonald, L., Beaulieu, M. et al. 2012, p. 4).

Although health care providers are well positioned to recognize abuse and neglect against older adults, the level of reporting of these types of cases is believed to be substantially lower than its true incidence (Almogue, Weiss, Marcus, \& Beloosesky, 2010; Bond \& Butler, 2013; Polkastro \& Payne, 2014; Schmeidel, Daly, Rosenbaum, Schmuch, \& Jogerst, 2012). Potential barriers to recognizing and reporting abuse and neglect of older adults include their reluctance to acknowledge the abuse, health care professionals' limited knowledge, a lack of protocols to identify abuse, fear of liability, and the small number of services available to support older adults in these situations (Rodriguez, Wallace, Woolf, \& Mangione, 2006; Taylor, Bachuwa, Evans, \& Jackson-Johnson, 2006; Wei \& Herbers, 2004).
Furthermore, until recently, there existed no comprehensive clinical guidelines for preventing and addressing abuse and neglect of older adults applicable to the Canadian context. One of the reasons for this deficit is that the current body of research in this area is underdeveloped, related to the lack of development of theoretical models to understand abuse and neglect of older adults. A theory provides an explanation of why something happens the way it does; abuse and neglect are complex and multilayered experiences that require robust theoretical frameworks to guide an understanding as well as actions to address these concerns. Explanations as to why the field of abuse and neglect of older adults has been devoid of guiding theories include the fact that (a) abuse and neglect of older adults has only within the past several decades gained national attention, (b) recognition is limited at organizational and governmental levels of a need to support theory development, and (c) the field has tended to support the belief that caregiver stress sufficiently explains the occurrence of abuse and neglect in this population group.

In this article, we present the findings from a systematic review that we conducted to synthesize current research evidence on effective approaches to address and prevent abuse and neglect of older adults. The purpose of the review was to inform the development of a best-practice guideline specific to this health challenge. Linking evidence-based guidelines to practice facilitates high-quality nursing and health care for older clients. The purpose of this guideline is to disseminate evidence-based recommendations to clinicians in health care settings that are providing services to older adults, as well as health system administrators and policy makers.

\section{Methods}

Developing a search strategy requires a structured approach. As Gillespie and Gillespie (2003) wrote, "Start by framing a simple question ... this can be refined to specify all the concepts of interest to the ... condition" (p. 139). The question will influence the selection of the search terms.

\section{Expert Panel Creation and Selection of Guiding Questions for the Systematic Review}

In 2012, the Registered Nurses' Association of Ontario (RNAO) invited a broad group of experts to serve on an expert panel that would help inform and guide the development of the best-practice guideline. In total, 12 subject matter experts ranging from fields as diverse as nursing, medicine, social work, law, patient advocacy, education, and research formed the expert panel. The panel helped derive the following questions to guide 
the subsequent literature search that informed the systematic review.

1. What are the most effective ways for nurses (and other health care providers) to identify and assess for abuse and neglect of older adults?

2. What are the most effective ways for nurses (and other health care providers) to respond to the abuse and neglect of older adults?

3. What education do nurses (and other health care providers) need to effectively address abuse and neglect of older adults?

4. What prevention and health promotion strategies are recommended regarding abuse and neglect of older adults?

5. What organizational policies and system level supports are required to effectively prevent and address abuse and neglect of older adults (living in facilities and community settings)?

\section{Data Sources and Search Strategy}

A comprehensive search strategy was developed through an iterative process between a health sciences librarian and the RNAO's research team consisting of two nursing research associates (NRA) and a master's-levelprepared nurse manager. Two literature searches were conducted by the librarian in the following databases: Cumulative Index to Nursing and Allied Health (CINAHL), Cochrane Controlled Trials (CT), Cochrane Systematic Reviews (SR), Database of Abstracts of Reviews of Effectiveness (DARE), Embase, Joanna Briggs Institute, Medline, Medline in Progress, Ovid Healthstar, and PsycINFO. We conducted the first search to select literature published between January 2000 and April 2013 and focused on the question, What are the most effective ways for nurses (and other health care providers) to identify, assess, and respond to abuse and neglect of older adults? The second search was conducted from January 2000-May 2013 and focused on the question, what are the most effective ways to prevent and address abuse and neglect of older adults (living in facilities and community settings)?

Keywords and subject headings relating to the abuse and neglect of older adults were used in each database. Search terms included but were not limited to the following: older adult, mistreatment, risk factor, screening, abuse, education, and best practices. As a generic term, "abuse" was selected because it was more generic in scope versus individual types of abuse being used as search terms. Terms were used alone and in combination. Expert panel members were also asked to review personal libraries to identify records. These were included if the two NRAs independently determined that the records had not been identified by the literature search and met the inclusion criteria. Results from all databases and records submitted were exported into bibliographic management software and merged to form a single database; duplicate citations were removed.

\section{Study Selection and Quality Appraisal Process}

The research team, in collaboration with the expert panel, developed inclusion and exclusion criteria . Inclusion criteria included (a) primary focus on abuse and neglect of older adults; (b) population aged 55 and older; (c) published in English or French in a peer-reviewed journal; (d) relevant to the scope of nursing, any health setting, or sector; and (e) records accessible for retrieval, any study type. Commentaries, dissertations, letters to the editor, editorials, papers less than one page in length, and study designs protocols were excluded.

Two NRAs independently screened each title and abstract of the records retrieved according to inclusion and exclusion criteria. Full text of the included records was then assessed for relevance according to the same a priori criteria used for the initial review. Any discrepancies arising throughout the screening process (between NRAs) were resolved by the program manager. The NRA determined inter-rater reliability by independently quality appraising 10 per cent of the included full-text records. Once a sufficient kappa score $(\kappa=0.76)$ was achieved, the remaining studies were divided equally between the NRA for independent quality appraisal and data extraction (Fleiss, Levin, \& Paik, 2003).

Appraisal tools were selected based on study design and included Critical Appraisal Skills Programme (CASP) for randomized control trials, qualitative studies, and observational studies; Assessing the Methodological Quality of Systematic Reviews (AMSTAR) for systematic reviews; Quasi-experimental Tool adapted from Cochrane Public Health (n.d.) for quasi-experimental studies; and Evaluation Tool for Mixed Methods studies for studies employing more than one type of research method (Long, Godfrey, Randall, Brettle, \& Grant, 2002). Using the appropriate tool, we scored each study and gave it an overall score that reflected the study's quality. Quality ratings included strong, moderate, or weak (see Table 1). Although quality rating tools as measures of article merit are still evolving, they nonetheless provide a method of quality assurance to the systematic review process.

\section{Data Extraction and Analysis}

From all records selected for full-text review, we extracted data for information on authors, study type, purpose, data collection methods, measures, data analysis, results, conclusions, and limitations. Data extraction tables were organized according to the identified search question and further organized by study type (see Table 1). The results of all studies were grouped into a thematic table, which we used to organize and summarize findings. The table outlined the main findings found among the results, conclusions of the study, and 
Table 1: Quality rating of evidence specific to research question

\begin{tabular}{|c|c|c|c|c|}
\hline Research Question & Citations & Study Type & Quality Rating & Key Findings \\
\hline \multirow[t]{10}{*}{$\begin{array}{l}\text { Identifying and } \\
\text { Assessing For } \\
\text { Abuse and Neglect } \\
\text { of Older Adults }\end{array}$} & Cohen et al. (2007) & Cross-sectional & Strong & $\begin{array}{l}\text { The use of all three assessment tools is needed for optimal identification of } \\
\text { abuse since no single assessment method is optimal: (1) direct questions to } \\
\text { elicit disclosure of abuse if it exists, (2) identification of evident signs of } \\
\text { abuse, and (3) assessment of high risk for abuse. }\end{array}$ \\
\hline & Hirst (2002) & Qualitative & Strong & $\begin{array}{l}\text { The study developed a taxonomy of resident abuse to articulate a definition } \\
\text { of the term based on the views of registered nurses. Identifying a common } \\
\text { definition of resident abuse suggests that assessment and intervention to } \\
\text { reduce episodes of it are more likely to be effective. }\end{array}$ \\
\hline & $\begin{array}{r}\text { Perez-Carceles } \\
\text { et al. (2009) }\end{array}$ & Cross-sectional & Strong & $\begin{array}{l}\text { The risk factors associated with elder abuse are recent worsening of health, } \\
\text { living with a mentally ill person, excessively consuming alcohol or illegal } \\
\text { drugs, arguing frequently with relatives, or depending on someone to } \\
\text { carry out a daily activity. } \\
\text { The signs in the physical examination associated are dehydration/ } \\
\text { malnutrition, pressure ulcers, and poor body and/or mouth hygiene. }\end{array}$ \\
\hline & Cohen et al. (2010) & Cross-sectional & Moderate & $\begin{array}{l}\text { Direct questioning mainly discloses instances of disrespectful behaviours and } \\
\text { humiliation, while the assessment of signs of abuse is more sensitive to } \\
\text { cases of neglect. } \\
\text { Routine screening for indicators of abuse is recommended to improve } \\
\text { detection and thereby to prevent abuse in long-term care facilities. }\end{array}$ \\
\hline & Davies et al. (2011) & Qualitative & Moderate & $\begin{array}{l}\text { Only three case features ('cues') appeared to be used in determining } \\
\text { whether elder financial abuse was occurring: (1) the route or path through } \\
\text { which the case emerged, (2) the mental capacity of the client, and (3) the } \\
\text { nature of the financial anomalies. }\end{array}$ \\
\hline & Goergen $(2004)^{a}$ & Mixed-methods & Moderate & $\begin{array}{l}\text { The study provided data on prevalence and incidence of a number of } \\
\text { abusive and neglectful behaviours and permitted analysis of variables that } \\
\text { can predict risks of victimization. }\end{array}$ \\
\hline & $\begin{array}{l}\text { Wiglesworth et al. } \\
\text { (2009) }\end{array}$ & Cross-sectional & Moderate & $\begin{array}{l}\text { Older adults who present with large }(45 \mathrm{~cm}) \text { bruises on the face, lateral right } \\
\text { arm, or posterior torso may be experiencing physical elder mistreatment. } \\
\text { Older adults with bruises should be asked about the cause of the bruises } \\
\text { to help ascertain whether physical abuse occurred. }\end{array}$ \\
\hline & Caldwell et al. (2013) & Integrative review & Weak & $\begin{array}{l}\text { None of the studies reviewed provided evidence on whether screening for } \\
\text { elder abuse reduces harm and risk of premature death and disability. }\end{array}$ \\
\hline & Cohen (2011) & Review & Weak & $\begin{array}{l}\text { Ideally, the below three screening modes are needed to optimize } \\
\text { identification of cases of abuse. It has been shown that each mode } \\
\text { identifies cases not identified by the other two: (1) direct questioning or } \\
\text { self-reports, (2) inspecting for signs of abuse, and (3) evaluating risk of } \\
\text { abuse. }\end{array}$ \\
\hline & Fulmer et al. $(2003)^{a}$ & Qualitative & Weak & $\begin{array}{l}\text { Elder neglect is a complex phenomenon that requires a multifaceted } \\
\text { approach for the diagnosis of cases. } \\
\text { An expert team provides long-standing experience and credibility for the } \\
\text { final assessment and diagnosis. }\end{array}$ \\
\hline
\end{tabular}

erez-Carceles

et al. (2009)

Cohen et al. (2010) 
Table 1: Continued

\begin{tabular}{|c|c|c|c|c|}
\hline Research Question & Citations & Study Type & Quality Rating & Key Findings \\
\hline & $\begin{array}{l}\text { Joubert and Posenelli } \\
\text { (2009) }\end{array}$ & Mixed-methods & Weak & $\begin{array}{l}\text { Staff suspicion of elder abuse was aroused during their observation of the } \\
\text { patient and their family or carer }(22 \%) \text {, during routine assessment }(46 \%) \\
\text { or when the elderly person was referred to them by another member of the } \\
\text { staff }(32 \%) \text {. }\end{array}$ \\
\hline & $\begin{array}{l}\text { Lindbloom et al. } \\
(2007)^{\mathrm{a}}\end{array}$ & Systematic review & Weak & $\begin{array}{l}\text { The study identified types of elder mistreatment, risk factors, and markers for } \\
\text { mistreatment in the nursing home environment. }\end{array}$ \\
\hline & Murphy et al. (2013) & Literature review & Weak & $\begin{array}{l}\text { Reports on the types of physical injuries common in elder abuse elicited the } \\
\text { following injury patterns: (1) skull and brain, (2) maxillofacial and neck, } \\
\text { (3) torso, (4) upper extremity, and (5) lower extremity. }\end{array}$ \\
\hline & Sandmoe (2007) & Literature review & Weak & $\begin{array}{l}\text { The phenomenon of elder abuse is complex and difficult to cover in one } \\
\text { instrument. }\end{array}$ \\
\hline & & & & $\begin{array}{l}\text { Standardized instruments lack the capability to detect all the facets of the } \\
\text { situation in which abuse occurs; therefore, their applicability in practice is } \\
\text { problematic. }\end{array}$ \\
\hline & $\begin{array}{l}\text { Tetterton and } \\
\text { Farnsworth }(2011)^{a}\end{array}$ & Qualitative & Weak & $\begin{array}{l}\text { Human service providers, including doctors, nurses, social workers, and } \\
\text { counselors should regularly screen for intimate partner violence in women } \\
\text { over the age of } 60 \text {. }\end{array}$ \\
\hline \multirow[t]{7}{*}{$\begin{array}{l}\text { Responding to the } \\
\text { Abuse and Neglect } \\
\text { of Older Adults }\end{array}$} & Ploeg et al. (2009) & Systematic review & Strong & $\begin{array}{l}\text { Findings suggest that there is currently insufficient evidence to support any } \\
\text { particular intervention related to elder abuse targeting clients, } \\
\text { perpetrators, or health care professionals. }\end{array}$ \\
\hline & Selwood et al. (2009) & Cross-sectional & Strong & $\begin{array}{l}\text { When family carers of people with dementia were asked which interventions } \\
\text { were most important, medication to help memory }(18.6 \%) \text {, home care } \\
(15.0 \%) \text {, and residential respite and sitting services }(10.6 \%) \text { were most } \\
\text { frequently endorsed. }\end{array}$ \\
\hline & & & & $\begin{array}{l}\text { A good starting point for evaluating interventions to reduce abuse by family } \\
\text { carers may be the expressed wishes of family carers themselves. }\end{array}$ \\
\hline & Zink et al. $(2004)^{a}$ & Qualitative & Strong & $\begin{array}{l}\text { Older victims of intimate partner violence described positive experiences } \\
\text { with health care providers when the provider listened, was empathetic, } \\
\text { and was knowledgeable about appropriate referrals. }\end{array}$ \\
\hline & Begley et al. $(2012)^{a}$ & Qualitative & Moderate & $\begin{array}{l}\text { The implication of the findings from this study is that enhanced attention and } \\
\text { resources should be directed to community activities that enable older } \\
\text { people to share their concerns informally, thereby gaining confidence to } \\
\text { seek more formal interventions when necessary. }\end{array}$ \\
\hline & Clancy et al. (2011) & Cross-sectional & Moderate & $\begin{array}{l}\text { The provision of elder abuse services to a wide range of referrals } \\
\text { demonstrated a therapeutic added benefit of specialist elder abuse } \\
\text { services. }\end{array}$ \\
\hline & Cooper et al. (2010) & $\begin{array}{l}\text { Longitudinal } \\
\text { study }\end{array}$ & Moderate & $\begin{array}{l}\text { Most abusive behaviour reported by carers at baseline persisted or } \\
\text { worsened in the following year, despite contact with specialist services. } \\
\text { The effectiveness of current interventions to respond to abuse and neglect } \\
\text { need to be evaluated. }\end{array}$ \\
\hline
\end{tabular}




\begin{tabular}{|c|c|c|c|c|}
\hline Research Question & Citations & Study Type & Quality Rating & Key Findings \\
\hline & Harbison et al. (2005) & Qualitative & Moderate & $\begin{array}{l}\text { The data from this study demonstrates that professional and lay workers in } \\
\text { rural communities, through collaboration, are able to transcend the } \\
\text { narrowness of legislative and formal provisions for service in order to } \\
\text { provide effective, culturally appropriate assistance to older people } \\
\text { suffering abuse and neglect. }\end{array}$ \\
\hline & \multirow[t]{2}{*}{$\begin{array}{l}\text { Killick and Taylor } \\
(2009)^{a}\end{array}$} & \multirow[t]{2}{*}{ Systematic review } & \multirow[t]{2}{*}{ Moderate } & $\begin{array}{l}\text { The decisions made in protecting adults can directly impinge on their } \\
\text { self-determination or safety and alleged victims should be active } \\
\text { participants in processes that affect their lives. }\end{array}$ \\
\hline & & & & $\begin{array}{l}\text { Good practice requires clear processes of reporting within teams and } \\
\text { collaboration among social work, medical, and law enforcement staff. }\end{array}$ \\
\hline & $\begin{array}{l}\text { Malmedal et al. } \\
(2009)^{a}\end{array}$ & Cross-sectional & Moderate & $\begin{array}{l}\text { Overall, nursing staff in nursing homes had a positive attitude about } \\
\text { reporting inadequate care. Sixty-six percent of staff moderately or strongly } \\
\text { agreed with the statement that whether or not they would report the act } \\
\text { would depend on its severity. }\end{array}$ \\
\hline & \multirow[t]{2}{*}{$\begin{array}{l}\text { Sandmoe and } \\
\quad \text { Kirkevold }(2013)^{a}\end{array}$} & \multirow[t]{2}{*}{ Qualitative } & \multirow[t]{2}{*}{ Moderate } & $\begin{array}{l}\text { Nurse managers emphasized the need for an individualized approach to } \\
\text { older victims suspected of being abused. }\end{array}$ \\
\hline & & & & $\begin{array}{l}\text { Nurse managers and community care staff need to be supported by } \\
\text { increased interdisciplinary collaboration to handle complex cases. }\end{array}$ \\
\hline & $\begin{array}{l}\text { Sandmoe et al. } \\
(2011)^{a}\end{array}$ & Qualitative & Moderate & $\begin{array}{l}\text { Community care agencies in Norway and Australia both struggle with } \\
\text { similar problems in handling cases of abuse. The nurses and care } \\
\text { coordinators in the study were concerned with securing and supporting } \\
\text { the older victim by individualizing the intervention. }\end{array}$ \\
\hline & $\begin{array}{l}\text { Vladescu et al. } \\
\text { (2000) }\end{array}$ & Cross-sectional & Moderate & $\begin{array}{l}\text { Informing the older client about possible actions and services they can use to } \\
\text { lessen the abusive situation is more important than trying to "take" the } \\
\text { victim away from the abuser. }\end{array}$ \\
\hline & \multirow[t]{2}{*}{$\begin{array}{l}\text { Beaulieu and Leclerc } \\
(2006)^{a}\end{array}$} & \multirow[t]{2}{*}{ Qualitative } & \multirow[t]{2}{*}{ Weak } & $\begin{array}{l}\text { The choice of interventions with a clientele of abused older adults and their } \\
\text { abusers depends on the evolution of three variables: (1) the loss of } \\
\text { autonomy of the older person, (2) the dangerousness of the situation, and } \\
\text { (3) the collaboration between the three parties (victim, abuser, and } \\
\text { practitioner). }\end{array}$ \\
\hline & & & & $\begin{array}{l}\text { Respect of the older person emerged as a meta-value that transcends all } \\
\text { actions. }\end{array}$ \\
\hline & Cripps $(2001)^{a}$ & $\begin{array}{l}\text { Retrospective } \\
\text { cohort }\end{array}$ & Weak & $\begin{array}{l}\text { The rights-focused advocacy model is a holistic model that is effective in } \\
\text { supporting older people to take steps to overcome the abuse that they } \\
\text { experience. }\end{array}$ \\
\hline & Heath et al. $(2005)^{a}$ & $\begin{array}{l}\text { Retrospective } \\
\text { cohort study }\end{array}$ & Weak & $\begin{array}{l}\text { An in-home geriatric assessment service (i.e., by a nurse practitioner- } \\
\text { geriatrician physician team) was able to contribute at least one relevant } \\
\text { intervention for } 81 \% \text { of referred adult protective service clients to } \\
\text { collaboratively help mitigate elder mistreatment circumstances. }\end{array}$ \\
\hline & \multirow[t]{2}{*}{ Lithwick et al. (2000) } & \multirow[t]{2}{*}{ Mixed-methods } & \multirow[t]{2}{*}{ Weak } & $\begin{array}{l}\text { There were varying degrees of success with the interventions in stopping or } \\
\text { reducing mistreatment of the older adult. }\end{array}$ \\
\hline & & & & $\begin{array}{l}\text { Researchers suggest the harm reduction model for an intervention } \\
\text { framework. }\end{array}$ \\
\hline
\end{tabular}

almedal et a

andmoe and

andmoe et al.

(2011)

adescu et a

eaulieu and Leclerc $(2006)^{a}$

Cripps (2001)

trospective 
Table 1: Continued

\begin{tabular}{|c|c|c|c|c|}
\hline Research Question & Citations & Study Type & Quality Rating & Key Findings \\
\hline & $\begin{array}{l}\text { Nahmiash and Reis } \\
(2000)^{a}\end{array}$ & Qualitative & Weak & $\begin{array}{l}80 \% \text { of the overall intervention strategies for abused older adults are rated } \\
\text { as successful or partially successful, and } 20 \% \text { are rated as unsuccessful. } \\
\text { It is pertinent for intervenors to focus services and strategies on abusers, in } \\
\text { particular offering them supportive individual counseling to reduce } \\
\text { anxiety, stress, and depression. }\end{array}$ \\
\hline & $\begin{array}{l}\text { Tetterton and } \\
\text { Farnsworth }(2011)^{a}\end{array}$ & Qualitative & Weak & $\begin{array}{l}\text { Providers must consider contextual factors when working with older women } \\
\text { who have experienced intimate partner violence such as individual, } \\
\text { couple, family, community, and cultural influences. }\end{array}$ \\
\hline & $\begin{array}{l}\text { Wiglesworth et al. } \\
(2006)^{a}\end{array}$ & Mixed-methods & Weak & $\begin{array}{l}\text { Survey results indicated that all collaborating groups (i.e., adult protection } \\
\text { service, the Vulnerable Adult Specialist Team, the district attorney's office, } \\
\text { law enforcement, and the public guardian's office) were enthusiastic about } \\
\text { the enhanced efficiency and effectiveness they were able to achieve } \\
\text { through working together with the Elder Abuse Forensic Center (EAFFC) to } \\
\text { manage and process abuse cases. } \\
\text { Case studies showed efficient and effective case management through } \\
\text { cooperation of the collaborating agencies. }\end{array}$ \\
\hline \multirow[t]{6}{*}{$\begin{array}{l}\text { Education Needed to } \\
\text { Effectively Address } \\
\text { Abuse and Neglect } \\
\text { of Older Adults }\end{array}$} & Jogerst et al. (2003)a & Cohort & Strong & $\begin{array}{l}\text { Results indicated that education for mandatory reporters has not impacted } \\
\text { investigation or substantiation rates of elder abuse. For example, there } \\
\text { were no significant differences in investigation rates for the four time } \\
\text { periods and no significant increase in investigation rates over time. }\end{array}$ \\
\hline & $\begin{array}{l}\text { Podnieks et al. } \\
(2010)^{a}\end{array}$ & Cross-sectional & Strong & $\begin{array}{l}\text { Most professionals lacked a good understanding of laws to protect older } \\
\text { adults. } \\
\text { Barriers to accessing information included a lack of Internet accessibility and } \\
\text { a lack of familiarity with resources. }\end{array}$ \\
\hline & $\begin{array}{l}\text { Rodriguez et al. } \\
(2006)^{a}\end{array}$ & Qualitative & Strong & $\begin{array}{l}\text { Primary care physicians appear to be subject to paradoxes of reporting that } \\
\text { contribute to the underreporting of elder abuse. } \\
\text { These paradoxes and alternative modes of managing paradoxes are } \\
\text { important and should be addressed in educational and training programs } \\
\text { for physicians. }\end{array}$ \\
\hline & Zink et al. (2004) ${ }^{a}$ & Qualitative & Strong & $\begin{array}{l}\text { Health care professionals providing care to older female victims of intimate } \\
\text { partner violence should identify signals of potential abuse (i.e., pick up on } \\
\text { hints or signals that something is wrong) and be knowledgeable about } \\
\text { appropriate referrals. }\end{array}$ \\
\hline & $\begin{array}{l}\text { Almogue et al. } \\
(2010)^{a}\end{array}$ & Cross-sectional & Moderate & $\begin{array}{l}\text { The main finding was that nurses and physicians had a low level of } \\
\text { knowledge of elder abuse issues and the relevant laws and regulations. } \\
\text { This study emphasizes the need to take more efficient measures to improve } \\
\text { the knowledge of the medical and nursing staff concerning elder abuse. }\end{array}$ \\
\hline & Begley et al. $(2012)^{a}$ & Qualitative & Moderate & $\begin{array}{l}\text { Older adults reported negative perceptions of formal social service } \\
\text { responses not being helpful or appropriate as one reason for non- } \\
\text { disclosure of abuse. }\end{array}$ \\
\hline
\end{tabular}




\begin{tabular}{|c|c|c|c|c|}
\hline Research Question & Citations & Study Type & Quality Rating & Key Findings \\
\hline & Dow et al. (2013) & Cross-sectional & Moderate & $\begin{array}{l}\text { There is a need for further definition clarification and education about } \\
\text { detection and management of elder abuse for health students and } \\
\text { professionals. } \\
\text { Student education should include consideration of the real-life situations } \\
\text { likely to be encountered in practice. Education for both students and } \\
\text { health professionals should include strategies for carers to manage difficult } \\
\text { situations. }\end{array}$ \\
\hline & $\begin{array}{l}\text { Killick and Taylor } \\
(2009)^{a}\end{array}$ & Systematic review & Moderate & $\begin{array}{l}\text { Good practice requires clear processes of reporting within teams and } \\
\text { collaboration among social work, medical, and law enforcement staff. } \\
\text { Adult protection staff should be supported by training and the development } \\
\text { of clear intra- and interagency systems. }\end{array}$ \\
\hline & Ko and Koh $(2012)^{a}$ & Cross-sectional & Moderate & $\begin{array}{l}\text { In order to increase nurses' reporting, education on elder abuse should be } \\
\text { provided to all nurses, and support programs should be designed for } \\
\text { nurses to effectively involve them in reporting elder abuse. }\end{array}$ \\
\hline & $\begin{array}{l}\text { Malmedal et al. } \\
(2009)^{a}\end{array}$ & Cross-sectional & Moderate & $\begin{array}{l}\text { Nurses with a higher educational level had a more positive attitude towards } \\
\text { willingness to report inadequate care committed by their colleagues and } \\
\text { less fear of negative sanctions. } \\
\text { Institutions need to develop and implement mechanisms for understanding } \\
\text { and evaluating acts of inadequate care, and staff must be encouraged to } \\
\text { speak out on behalf of residents rather than be punished for doing so. }\end{array}$ \\
\hline & $\begin{array}{l}\text { Richardson et al. } \\
(2002)\end{array}$ & $\begin{array}{l}\text { Randomized } \\
\text { control trial }\end{array}$ & Moderate & $\begin{array}{l}\text { The main findings of this study were that there was a lack of knowledge of } \\
\text { good management in dealing with elder abuse among health care } \\
\text { professionals, and that educational seminars were superior to printed } \\
\text { material in increasing knowledge and good management in this field. } \\
\text { Educational needs to be targeted to take into account the baseline } \\
\text { knowledge. }\end{array}$ \\
\hline & Saliga et al. (2004) & Cross-sectional & Moderate & $\begin{array}{l}\text { This study identified a lack of knowledge in recognition and management of } \\
\text { elder abuse including Michigan's mandatory reporting law among } \\
\text { physical therapists. Although required by law, all therapists that suspected } \\
\text { abuse did not report their suspicions to proper legal authorities. Continued } \\
\text { professional education and research in this area is needed. }\end{array}$ \\
\hline & $\begin{array}{l}\text { Schmeidel et al. } \\
(2012)^{a}\end{array}$ & Qualitative & Moderate & $\begin{array}{l}\text { More frequent and pragmatic education is necessary to strengthen practical } \\
\text { knowledge about elder abuse in the minds of nurses and physicians. This } \\
\text { education should stress maintaining personal responsibility and fulfilling } \\
\text { one's personal role in reporting abuse within the use of an } \\
\text { interdisciplinary medical team. }\end{array}$ \\
\hline
\end{tabular}




\begin{tabular}{|c|c|c|c|c|}
\hline Research Question & Citations & Study Type & Quality Rating & Key Findings \\
\hline & Teresi et al. (2013) & $\begin{array}{l}\text { Randomized } \\
\text { control trial }\end{array}$ & Moderate & $\begin{array}{l}\text { The study demonstrated that a training intervention for nursing staff was } \\
\text { effective in enhancing knowledge, recognition and reporting of resident-to- } \\
\text { resident elder mistreatment (R-REM) in nursing homes. It is recommended } \\
\text { that this training program be implemented in long-term care facilities. }\end{array}$ \\
\hline & Winterstein (2012) & Qualitative & Moderate & $\begin{array}{l}\text { Nursing education should be challenged with elder mistreatment in general, } \\
\text { and elder neglect in particular. }\end{array}$ \\
\hline & & & & $\begin{array}{l}\text { Training and educational programs should provide a platform on which to } \\
\text { raise dilemmas concerning the encounter with this subject. }\end{array}$ \\
\hline & $\begin{array}{l}\text { Beaulieu and Leclerc } \\
(2006)^{a}\end{array}$ & Qualitative & Weak & $\begin{array}{l}\text { Many of the findings of this study regarding ethical dilemmas in elderly adult } \\
\text { mistreatment situations for practitioners could be transformed into useful } \\
\text { training material. }\end{array}$ \\
\hline & Cooper et al. (2009) & Systematic review & Weak & $\begin{array}{l}\text { Most elder abuse remains undetected and unreported. Educational } \\
\text { interventions for health care professionals in the form of group face-to-face } \\
\text { teaching or videos can increase their knowledge about abuse. }\end{array}$ \\
\hline & Wong \& Marr (2002) & Cross-sectional & Weak & $\begin{array}{l}\text { Postgraduate training in elder abuse was associated with improved scores in } \\
\text { knowledge of history and physical and legal aspects of elder abuse for } \\
\text { physicians, dietitians, occupational therapists, nurses, and social workers. } \\
\text { These results suggest possible improvements to the detection and } \\
\text { management of elder abuse via post-education training and on-site } \\
\text { availability of written protocols. }\end{array}$ \\
\hline \multirow[t]{2}{*}{$\begin{array}{l}\text { Prevention and } \\
\text { Health Promotion } \\
\text { Strategies }\end{array}$} & $\begin{array}{l}\text { Podnieks et al. } \\
(2010)^{a}\end{array}$ & Cross-sectional & Strong & $\begin{array}{l}\text { For developed nations, funding, awareness of elder abuse, and better } \\
\text { policies were reported as the major changes that could ameliorate elder } \\
\text { abuse and address the needs of older adults. }\end{array}$ \\
\hline & Begley et al. $(2012)^{a}$ & Qualitative & Moderate & $\begin{array}{l}\text { Older adults in this study felt that staying connected within their communities } \\
\text { and to their friends was a useful and necessary support to addressing and } \\
\text { preventing elder abuse. }\end{array}$ \\
\hline
\end{tabular}

Beaulieu and Leclerc

Cooper et al. (2009)

cCool et al

$(2009)^{a}$ preventing elder abuse. 


\begin{tabular}{|c|c|c|c|c|}
\hline Research Question & Citations & Study Type & Quality Rating & Key Findings \\
\hline & Hsieh et al. (2009) & $\begin{array}{l}\text { Quasi- } \\
\text { experimental }\end{array}$ & Moderate & $\begin{array}{l}\text { An educational support group intervention that provides stress relief, support, } \\
\text { and material training to caregivers of care-dependent older adults was } \\
\text { found to have significant effects in alleviating caregiver psychological abuse } \\
\text { behavior and increasing care-giving knowledge in the intervention group. }\end{array}$ \\
\hline & Jogerst et al. $(2001)^{a}$ & Cross-sectional & Moderate & $\begin{array}{l}\text { Nearly three-fourths of investigators working in Adult Protective Service } \\
\text { reported that elder abuse was under-reported in their area due to lack of } \\
\text { public awareness or concern, and a fear of the system. }\end{array}$ \\
\hline & Koch and Nay (2003) & Qualitative & Moderate & $\begin{array}{l}\text { Participants clearly identified that a preventive approach is integral in the } \\
\text { successful reduction of abuse and that any formal intervention needs to } \\
\text { reflect the unique set of circumstances pertaining to abuse of each person } \\
\text { with dementia and/or their carers. }\end{array}$ \\
\hline & $\begin{array}{l}\text { Reay and Browne } \\
\quad(2002)\end{array}$ & $\begin{array}{l}\text { Quasi- } \\
\text { experimental }\end{array}$ & Moderate & $\begin{array}{l}\text { An education and anger management intervention program for individuals } \\
\text { who physically abuse or neglect their elderly dependents was effective in } \\
\text { reducing their strain, depression, and anxiety. }\end{array}$ \\
\hline & Wolf $(2001)^{a}$ & Cross-sectional & Moderate & $\begin{array}{l}\text { Recommendations for support groups that are designed specifically for older } \\
\text { victims of abuse include insuring accessibility of meeting site; using a leader } \\
\text { and co-leader, at least one of whom is older or familiar with aging issues; } \\
\text { allocating resources for recruitment; and seeking a steady source of funding. }\end{array}$ \\
\hline & Cripps $(2001)^{a}$ & $\begin{array}{l}\text { Retrospective } \\
\text { cohort }\end{array}$ & Weak & $\begin{array}{l}\text { The Rights Focused Advocacy Model enabled older people to take steps to } \\
\text { stop abuse in } 50 \% \text { of those situations, and to take some action in } 34 \% \text { of } \\
\text { situations. }\end{array}$ \\
\hline & $\begin{array}{l}\text { Nahmiash and Reis } \\
(2000)^{a}\end{array}$ & Qualitative & Weak & $\begin{array}{l}\text { For abused care receivers, home-based services can offer the necessary } \\
\text { support to move out of their abuse situation with the help of volunteers and } \\
\text { support group activities. }\end{array}$ \\
\hline & Proehl (2012) & Cross-sectional & Weak & $\begin{array}{l}\text { An innovative approach of working with the faith community to prevent and } \\
\text { report elder abuse may be beneficial to older adults and may have great } \\
\text { promise for preventing elder abuse. }\end{array}$ \\
\hline \multirow{4}{*}{$\begin{array}{l}\text { Organizational } \\
\text { Policies and } \\
\text { System Level } \\
\text { Supports }\end{array}$} & Jogerst et al. $(2003)^{a}$ & Cohort & Strong & $\begin{array}{l}\text { Education for mandatory reporters has not impacted investigation or } \\
\text { substantiation rates for elder abuse in lowa. }\end{array}$ \\
\hline & $\begin{array}{l}\text { Lawrence and } \\
\text { Banerjee (2010) }\end{array}$ & Qualitative & Strong & $\begin{array}{l}\text { The assessment of a care home support team (CHST) demonstrated the } \\
\text { potential for specialist multi-disciplinary teams to raise standards of care } \\
\text { across long-term care settings. } \\
\text { Such services could be instrumental in preventing abuse among vulnerable } \\
\text { adults. }\end{array}$ \\
\hline & $\begin{array}{l}\text { Podnieks et al. } \\
(2010)^{a}\end{array}$ & Cross-sectional & Strong & $\begin{array}{l}\text { For developed nations, funding, awareness, and better policies were } \\
\text { reported as the major changes that could ameliorate elder abuse and } \\
\text { address the needs of older adults. }\end{array}$ \\
\hline & $\begin{array}{l}\text { Rodriguez et al. } \\
\qquad(2006)^{a}\end{array}$ & Qualitative & Strong & $\begin{array}{l}\text { Three paradoxes were expressed by physicians about the mandatory } \\
\text { reporting of elder abuse that contribute to the underreporting of elder } \\
\text { abuse: (1) physician-patient rapport/relationships, (2) patient quality of } \\
\text { life, and (3) presence and loss of physician control. }\end{array}$ \\
\hline
\end{tabular}




\begin{tabular}{|c|c|c|c|c|}
\hline Research Question & Citations & Study Type & Quality Rating & Key Findings \\
\hline & $\begin{array}{l}\text { Almogue et al. } \\
(2010)^{a}\end{array}$ & Cross-sectional & Moderate & $\begin{array}{l}\text { Both physicians and nurses tended to have neutral attitudes regarding elder } \\
\text { abuse. However, employees of geriatric hospitals had better attitudes than } \\
\text { general hospital workers. }\end{array}$ \\
\hline & $\begin{array}{l}\text { Buzgova and Ivanova } \\
\text { (2009) }\end{array}$ & Qualitative & Moderate & $\begin{array}{l}\text { It is necessary in residential settings to create preventive policies that will } \\
\text { focus on supervision regarding elderly people's rights violation and } \\
\text { psychological and physical abuse, as well as on building organizational } \\
\text { cultures that will respect ethical principles. }\end{array}$ \\
\hline & Goergen $(2004)^{a}$ & Mixed-methods & Moderate & $\begin{array}{l}\text { Stress-induced alcohol consumption, physically aggressive acts by older } \\
\text { residents, nurses' emotional exhaustion, and the ratio of older residents to } \\
\text { registered nurses on subjects' ward all contribute to the prediction of the } \\
\text { incidence of acts of abuse and neglect. }\end{array}$ \\
\hline & Jogerst et al. $(2001)^{a}$ & Cross-sectional & Moderate & $\begin{array}{l}\text { There is a need for increased and ongoing financial support for elder abuse } \\
\text { programs and staff. }\end{array}$ \\
\hline & Ko and Koh (2012) ${ }^{a}$ & Cross-sectional & Moderate & $\begin{array}{l}\text { Support programs should be designed for nurses to effectively involve them } \\
\text { in reporting elder abuse. }\end{array}$ \\
\hline & $\begin{array}{l}\text { Malmedal et al. } \\
(2009)^{a}\end{array}$ & Cross-sectional & Moderate & $\begin{array}{l}\text { Institutions need to develop and implement mechanisms for understanding } \\
\text { and evaluating acts of inadequate care. }\end{array}$ \\
\hline & $\begin{array}{l}\text { Phillips and Ziminski } \\
\text { (2012) }\end{array}$ & Cross-sectional & Moderate & $\begin{array}{l}\text { Public health nurses working with older adults residing in assisted living } \\
\text { facilities (ALF) and working in communities that have ALFs need to be } \\
\text { aware of the problem of neglect and its related outcomes and their role in } \\
\text { public policy and education. } \\
\text { Public health nurses working as facility inspectors need to be sensitive to the } \\
\text { relationship of institutional practices and staff inadequacies and neglect. }\end{array}$ \\
\hline & Saliga et al. (2004)a & Cross-sectional & Moderate & $\begin{array}{l}\text { Twenty-five percent of respondents had suspected abuse of one of their } \\
\text { patients; however, over half failed to report their suspicions. }\end{array}$ \\
\hline & $\begin{array}{l}\text { Sandmoe and } \\
\text { Kirkevold }(2013)^{a}\end{array}$ & Qualitative & Moderate & $\begin{array}{l}\text { Nurse managers and staff in community care need support to handle } \\
\text { complex elder abuse cases. }\end{array}$ \\
\hline & $\begin{array}{l}\text { Sandmoe et al. } \\
(2011)^{a}\end{array}$ & Qualitative & Moderate & $\begin{array}{l}\text { For community care nurses, the managers' support and the elder protective } \\
\text { services were of great importance to them when dealing with elder abuse } \\
\text { cases. }\end{array}$ \\
\hline & $\begin{array}{l}\text { Schmeidel et al. } \\
(2012)^{a}\end{array}$ & Qualitative & Moderate & $\begin{array}{l}\text { Although continuity in the external reporting system for elder abuse is } \\
\text { needed, many changes also can be made within the clinical setting that } \\
\text { may facilitate reporting elder mistreatment. }\end{array}$ \\
\hline & $\begin{array}{l}\text { Shinan-Altman and } \\
\text { Cohen }(2009)^{a}\end{array}$ & Cross-sectional & Moderate & $\begin{array}{l}\text { Condoning abusive behaviors was closely associated with higher levels of } \\
\text { work stressors, burnout, and low income for nursing aides working in } \\
\text { nursing homes. } \\
\text { Role ambiguity, role conflict, and burnout were significantly associated with } \\
\text { attitudes condoning abusive behaviours towards older adults. }\end{array}$ \\
\hline & Teaster et al. (2003) & Cross-sectional & Moderate & $\begin{array}{l}\text { Elder Abuse Multidisciplinary Teams (MDT) play a key role in communities' } \\
\text { response to elder abuse and are highly valued by those who participate. }\end{array}$ \\
\hline & Wolf $(2001)^{a}$ & Cross-sectional & Moderate & $\begin{array}{l}\text { A policy of collaboration among the state's domestic violence coalition, state } \\
\text { unit on aging, adult protective services, and victim assistance program may } \\
\text { help in promoting support group development and utilization for older adults. }\end{array}$ \\
\hline
\end{tabular}


Table 1: Continued

\begin{tabular}{|c|c|c|c|c|}
\hline Research Question & Citations & Study Type & Quality Rating & Key Findings \\
\hline & Fulmer et al. (2003)a & Qualitative & Weak & $\begin{array}{l}\text { The researchers found that an expert team provides long-standing } \\
\text { experience and credibility for the final assessment and diagnosis of } \\
\text { neglect of older adults. }\end{array}$ \\
\hline & Heath et al. $(2005)^{a}$ & $\begin{array}{l}\text { Retrospective } \\
\text { cohort study }\end{array}$ & Weak & $\begin{array}{l}\text { An in-home geriatric assessment service (i.e., by a nurse practitioner- } \\
\text { geriatrician physician team) was able to contribute at least one relevant } \\
\text { intervention for } 81 \% \text { of referred adult protective service clients to } \\
\text { collaboratively help mitigate elder mistreatment circumstances. }\end{array}$ \\
\hline & $\begin{array}{l}\text { Lindbloom et al. } \\
(2007)^{a}\end{array}$ & Systematic review & Weak & $\begin{array}{l}\text { Nursing home mistreatment is a complex phenomenon often involving an } \\
\text { overworked caregiver, in an underfunded care environment, mistreating a } \\
\text { functionally dependent resident who is unable or unwilling to seek help. } \\
\text { ldentification and prevention strategies to combat elder mistreatment in } \\
\text { nursing homes were identified in this review. Nursing homes should: } \\
\text { (1) focus on staff training, job satisfaction, and job turnover of employees; } \\
\text { (2) employ ombudsmen and keep records of abuse; and (3) report } \\
\text { suspicions of abuse. }\end{array}$ \\
\hline & $\begin{array}{l}\text { McCool et al. } \\
(2009)^{a}\end{array}$ & Mixed-methods & Weak & $\begin{array}{l}\text { Nursing home employees identified four themes related to mandatory } \\
\text { reporting of elder abuse which included (1) staff education/training, } \\
\text { (2) reporting decisions and judgment, (3) barriers to reporting, and } \\
\text { (4) abuse related to staff working conditions. } \\
\text { Establishing a separate investigating entity other than the nursing home } \\
\text { licensing agency may improve the likelihood that abuse in nursing homes } \\
\text { will be reported. }\end{array}$ \\
\hline & $\begin{array}{l}\text { Mosqueda et al. } \\
\text { (2004) }\end{array}$ & Cross-sectional & Weak & $\begin{array}{l}\text { Ninety-seven percent of those who referred cases to Vulnerable Adult } \\
\text { Protective Services (VAST) indicated that the team was helpful in } \\
\text { confirming abuse, documenting impaired capacity, reviewing medications } \\
\text { and medical conditions, facilitating the conservatorship process, } \\
\text { persuading the client or family to take action, and supporting the need for } \\
\text { law enforcement involvement. }\end{array}$ \\
\hline & $\begin{array}{l}\text { Wiglesworth et al. } \\
(2006)^{a}\end{array}$ & Mixed-methods & Weak & $\begin{array}{l}\text { An Elder Abuse Forensic Center (EAFC) enhances the efficiency and } \\
\text { effectiveness of those who address elder abuse in one community, which } \\
\text { in turn leads to improved outcomes. }\end{array}$ \\
\hline
\end{tabular}

\section{a Studies $(n=62)$ that are applicable to multiple thematic categories}

TOTAL QA SCORES:

Weak $=21$

Moderate $=31$

Strong $=10$ 
an explanation of the findings that aligned with the research question.

\section{Results}

\section{Identification of Eligible Studies}

The literature search returned 20,475 records, including 12 records submitted by the panel members. This was reduced to 13,064 records after removing duplicates, and further reduced to 816 records after we applied the inclusion and exclusion criteria to the abstracts.

Review of these articles resulted in 84 records that met the inclusion criteria, of which an additional 22 records were excluded based on their lack of applicability to the initial search questions. Of the 62 studies that met the overall inclusion criteria, quality appraisals resulted in 10 rated as strong, 31 as moderate, and 21 as weak. Weak studies were included in the review if the findings aligned with stronger studies and together formed a common theme, or to support the discussions of recommendations in the best-practice guideline (see Table 2). Figure 1 summarizes the records analysed as part of the review process.

The following is a summary of results according to the five guiding questions

\section{Identifying and Assessing For Abuse and Neglect of Older Adults}

Descriptive/observational and qualitative studies form the bulk of studies and reviews for identifying and assessing abuse and neglect. Six studies identified various markers, types, and risk factors associated with abuse and neglect of older adults (Davies et al., 2011; Goergen, 2004; Lindbloom, Brandt, Hough, \& Meadows,
2007; Murphy, Waa, Jaffer, Sauter, \& Chan, 2013; PerezCarceles et al., 2009; Wiglesworth et al., 2009). The main approaches to identify and assess for abuse and neglect of older adults (a) use combined and multifaceted approaches to assess for abuse and neglect (Cohen, 2011; Cohen, Levin, Gagin, \& Friedman, 2007; Fulmer et al., 2003; Sandmoe, 2007); (b) conduct screening in acute (e.g., emergency department) and subacute (e.g., rehabilitation care) health care settings (Joubert \& Posenelli, 2009); (c) routinely ask about abuse with direct questioning (Cohen, Halevy-Levin, Gagin, Prilutzky, \& Friedman, 2010; Tetterton \& Farnsworth, 2011); and (d) utilize the skills of an expert assessment team (Fulmer et al., 2003). One study indicated that there is a lack of evidence to determine if screening for abuse reduces harm (Caldwell, Gilden, \& Mueller, 2013). The majority of the studies specific to this question were of weak quality.

\section{Responding to the Abuse and Neglect of Older Adults}

Despite the fact that two studies indicated insufficient evidence to support any particular intervention for nurses and other health care providers to respond to abuse and neglect of older adults (Cooper, Blanchard, Selwood, Walker, \& Livingston, 2010; Ploeg, Fear, Hutchison, MacMillan, \& Bolan, 2009), three important features did emerge, including (a) individualizing the intervention to the older adult (Sandmoe \& Kirkevold, 2013; Sandmoe, Kirkevold, \& Ballantyne (2011); (b) utilizing multipronged and varied strategies (e.g., education and referrals) (Begley, O'Brien, Anand, Killick, \& Taylor, 2012; Zink, Jacobson, Regan, \& Pabst, 2004); and (c) implementing interventions acceptable to the older adult, family, and caregivers (Nahmiash \& Reis, 2000; Selwood, Cooper, Owens, Blanchard, \& Livingston,

Table 2: Summary of research questions, citations, and quality rating specific to the research questions explored in the study

\begin{tabular}{|c|c|c|}
\hline Research Question & Number of Citations & Quality Rating \\
\hline $\begin{array}{l}\text { What are the most effective ways for nurses (and other health care providers) } \\
\text { to identify and assess for abuse and neglect of older adults? }\end{array}$ & 15 & $\begin{array}{l}\text { Strong: } 3 \text { citations } \\
\text { Moderate: } 4 \text { citations } \\
\text { Weak: } 8 \text { citations }\end{array}$ \\
\hline $\begin{array}{l}\text { What are the most effective ways for nurses (and other health care providers) } \\
\text { to respond to the abuse and neglect of older adults? }\end{array}$ & 19 & $\begin{array}{l}\text { Strong: } 3 \text { citations } \\
\text { Moderate: } 9 \text { citations } \\
\text { Weak: } 7 \text { citations }\end{array}$ \\
\hline $\begin{array}{l}\text { What prevention and health promotion strategies are recommended regarding } \\
\text { abuse and neglect of older adults? }\end{array}$ & 10 & $\begin{array}{l}\text { Strong: } 1 \text { citations } \\
\text { Moderate: } 6 \text { citations } \\
\text { Weak: } 3 \text { citations }\end{array}$ \\
\hline $\begin{array}{l}\text { What organizational policies and system-level supports are required to effectively } \\
\text { prevent and address abuse and neglect of older adults (living in facilities and } \\
\text { community settings)? }\end{array}$ & 24 & $\begin{array}{l}\text { Strong: } 4 \text { citations } \\
\text { Moderate: } 14 \text { citations } \\
\text { Weak: } 6 \text { citations }\end{array}$ \\
\hline
\end{tabular}

n= 62 citations (some studies are applicable to multiple research questions) 


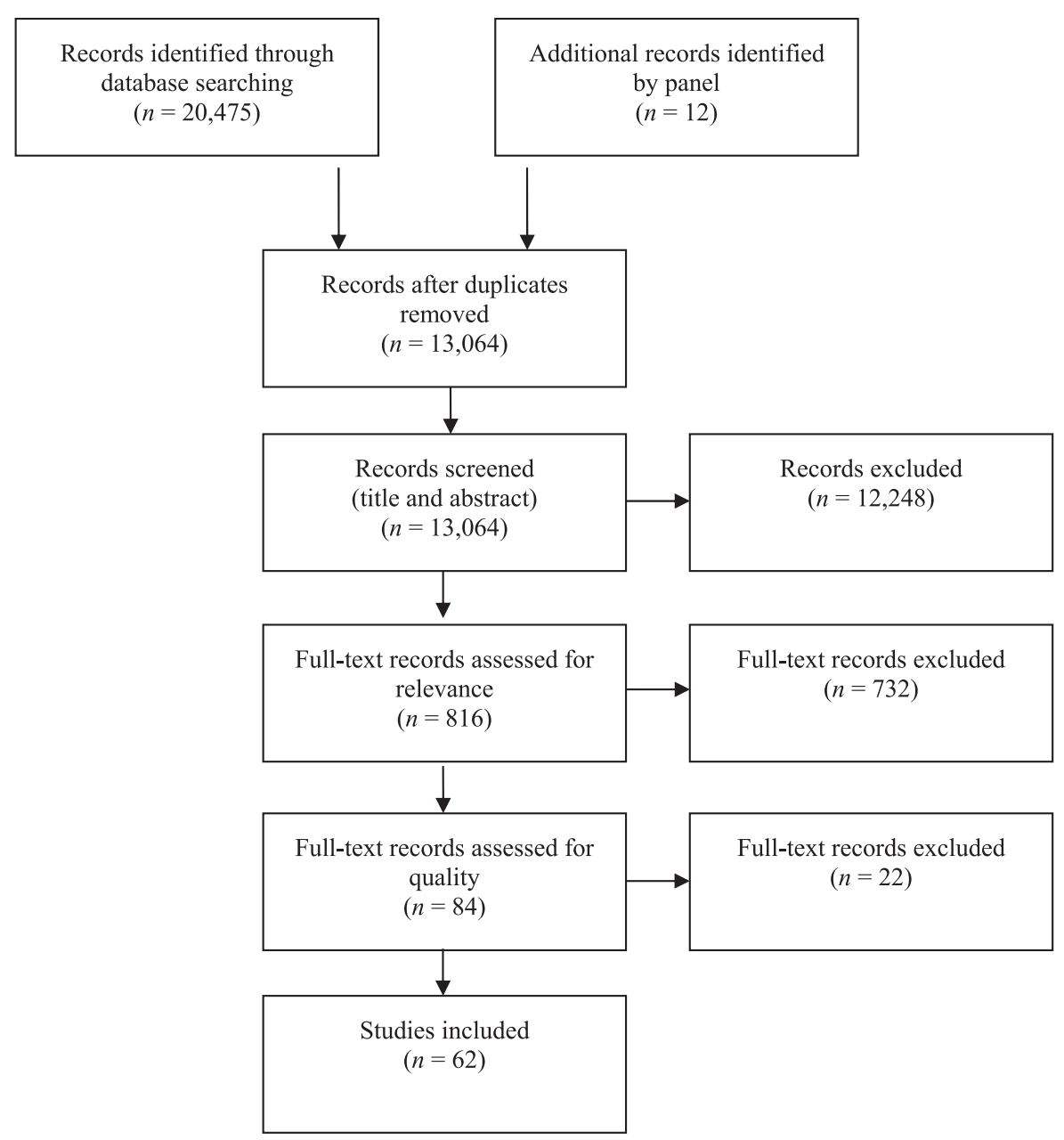

Figure 1: Identification of the 62 eligible studies found in the literature review for determining a best-practice guideline for preventing the abuse and neglect of older adults. Flow diagram adapted from "Preferred Reporting ltems for Systematic Reviews and Meta-analyses: The PRISMA Statement," by D. Moher, A. Liberati, J. Tetzlaff, D. G. Altman, and The PRISMA Group, 2009, British Medical Journal, 339, p. b2535

2009; Vladescu, Eveleigh, Ploeg, \& Patterson, 2000). Emotionally supportive, culturally considerate, and patientcentred approaches with a harm reduction focus were favoured in the literature (Beaulieu \& Leclerc, 2006; Cripps, 2001; Lithwick, Beaulieu, Gravel, \& Straka, 2000; Tetterton \& Farnsworth, 2011). Effectively responding to the abuse and neglect of older adults requires an interprofessional, collaborative, and coordinated approach (Clancy, McDaid, O'Neill, \& O'Brien, 2011; Harbison, Coughlan, Karabanow, \& VanderPlaat, 2005; Heath, Kobylarz, Brown, \& Castano, 2005; Killick \& Taylor, 2009; Wiglesworth, Mosqueda, Burnight, Younglove, \& Jeske, 2006). Overall, the majority of the studies specific to this question were of moderate to weak quality.

\section{Education Needed to Effectively Address Abuse and Neglect of Older Adults}

Three issues we identified that related to the education of health care providers were (a) a knowledge and training deficit around the abuse and neglect of older adults (i.e., how to recognize abuse, how to respond appropriately, laws related to reporting abuse) (Almogue et al., 2010; Podnieks, Anetzberger, Wilson, Teaster, \& Wangmo, 2010; Richardson, Kitchen, \& Livingston, 2002; Saliga, Adamowicz, Logue, \& Smith, 2004); (b) a hesitancy to report abuse and neglect even after education is provided (McCool, Jogerst, Daly, \& Xu, 2009); and (c) a gap between knowledge and practice in that education may increase knowledge about abuse but may not affect health ca1re provider behaviour (i.e., asking about or responding to abuse) (Jogerst, Daly, Dawson, Brinig, \& Schmuch, 2003). The literature on older adult abuse education programs have shown mixed results regarding their effectiveness, mainly whether the education programs lead to an increase in knowledge, assessment skills, and reporting of abuse and neglect by health care providers (Alt, Nguyen, \& Meurer, 2011; Jogerst et al., 2003; Mills et al., 2012; Teresi et al., 2013; Wong \& Marr, 2002). 
Despite these limitations and challenges, it is agreed in the literature that effective educational programs are needed so that health care providers have the knowledge to address abuse and neglect of older adults (Ko \& Koh, 2012; Meeks-Sjostrom, 2013). Specifically, education programs should address four key elements: (1) discuss ethical issues involved with abuse (Beaulieu \& Leclerc, 2006; Rodriguez et al., 2006; Winterstein (2012); (2) specify professional and legal responsibilities of health care providers when abuse and neglect is suspected or known (Killick \& Taylor, 2009; Malmedal, Hammervold, \& Saveman, 2009; Schmeidel et al., 2012); (3) use various training strategies focused on increasing knowledge in addressing abuse (Dow et al., 2013; Cooper, Selwood, \& Livingston, 2009; Zink et al., 2004), and (4) modify attitudes that condone abuse (Shinan-Altman \& Cohen, 2009). The majority of the studies specific to this question were of moderate quality.

\section{Prevention and Health Promotion Strategies}

Prevention and health promotion strategies targeted the older adult, the abusive caregiver, and the public. Strategies concerning older adults included community activities and supports that enable older people to disclose concerns and access assistance if needed. Examples include (a) implementing a rights-focused advocacy model to empower older adults to overcome abuse and (b) arranging for home-based supportive services, volunteer/buddy advocates, and the involvement of faith communities, community outreach, and support groups (Begley et al., 2012; Cripps, 2001; Nahmiash \& Reis, 2000; Proehl, 2012; Wolf, 2001). Strategies for the abusive caregiver included programs specifically targeting abusers (i.e., counselling to minimize stress, education, anger management), and education about caregiving for older adults with cognitive impairments such as dementia (Hsieh, Wang, Yen, \& Liu, 2009; Koch \& Nay, 2003; Reay \& Browne, 2002). Finally, suggested prevention strategies addressed public education about abuse and neglect of older adults, the rights of older adults, how to protect oneself from abuse, and awareness campaigns about abuse and neglect of older adults (Jogerst, Daly, \& Ingram, 2001). The majority of the studies specific to this question were of moderate quality.

\section{Organizational Policies and System Level Supports}

Six strategies emerged that underline how organizations and government systems can target abuse and neglect of older adults. These were (a) developing abuse/neglect of older adults assessment teams (Fulmer et al., 2003; Heath et al., 2005; Lawrence \& Banerjee, 2010; Mosqueda, Burnight, Liao, \& Kemp, 2004; Teaster,
Nerenberg, \& Stansbury, 2003; Wiglesworth et al., 2006); (b) improving working conditions in nursing homes (Goergen, 2004; Shinan-Altman \& Cohen, 2009); (c) supporting the supervision, tracking, and monitoring of abuse in nursing homes (Lindbloom et al., 2007; Malmedal et al., 2009; McCool et al., 2009; Phillips \& Ziminski, 2012; Schmeidel et al., 2012); (d) providing funding for abuse programs/services (Jogerst et al., 2001; Podnieks et al., 2010); (e) developing policies and protocols for responding and for training; and (f) creating supports for health care providers (Buzgova \& Ivanova, 2009; Ko, \& Koh, 2012; Sandmoe \& Kirkevold, 2013; Sandmoe et al., 2011).The literature pointed out the challenges and outcomes of mandatory reporting laws and policies (Saliga et al., 2004). Health care providers are not always aware of mandatory reporting laws and policies or how to enforce them. However, even after education is provided, not all providers comply for various reasons (e.g., not wanting to tell on a colleague) (Jogerst et al., 2003; Rodriguez et al., 2006). The majority of the studies specific to this question were of moderate quality.

\section{Discussion}

When reviewing a substantive body of evidence on a particular topic, it is important that the reviewers understand there is often a large degree of variability in the quality of existing research studies. Indeed, for our systematic review, the quality of the studies we reviewed significantly varied across the results, with only a few appraised as strong studies. The majority of these high-quality studies focused on describing abuse and neglect of older adults; very few focused on what could be done at the individual practitioner level and none at the organization level. This contributes to a number of concerns regarding the evidence that can inform us concerning this important issue.

There was no clear consensus on the definition and measurement of abuse among older adults. Differences in the prevalence of abuse or neglect and its components using the various definitions, both within and between populations of older adults, indicate that caution is required when comparing findings from different studies. Determining the significance of these differences will require prospective outcome studies. This lack of consistency will contribute to whether older adults are recognized as being abused. Indeed, a lack of consistent identification methods means that some older adults will not be identified and referred to appropriate services even as the abuse may continue.

Our review further indicated a lack of evidence to determine if screening for abuse actually reduces its occurrence; this was supported by the U.S. Preventive Services Task Force recommendation statement (2013), 
based on a systematic review of screening tools, that there is insufficient evidence about the benefits and harms of screening tools and raises doubts about their accuracy and effectiveness. Insufficient evidence also exists supporting the effectiveness of interventions to respond to abuse and neglect. There is a growing interest in providing intervention services for older victims of abuse along the lines of those developed for abused women. Emergency shelters and support groups specifically aimed at older abused adults are relatively new. However, few intervention programs have been formally evaluated, and it is not possible to say which approaches have been most effective.

Perhaps the most hurtful form of abuse against older adults, found in our review, lies generally in the negative attitudes held towards them. As long as older people are devalued by society, they will remain highly susceptible to all forms of abuse. Public awareness campaigns and educational initiatives are key to educating Canadians about abuse and neglect of older adults. Education is a fundamental preventive strategy and should be targeted to practitioners in the various relevant disciplines and to the public. Yet very little is known about the effectiveness of professional education and even less about public awareness campaigns to increase awareness and prevent abuse and neglect of older adults.

To continue to strengthen research evidence and related programs and policies, intervention strategies should be embedded in a rigorous research agenda. Future research should focus on understanding the effectiveness of different tools used to identify and assess for abuse and neglect and intervention approaches, and what works best in addressing this issue among the diversity of cultural groups in Canada.

Arising from the findings are areas rich for further investigation specific to abuse and neglect of older adults. Efforts to mobilize social action against this serious concern at an organizational, provincial/ territorial, and national level - and efforts to develop legislation and policy initiatives - are at varying stages of development. However, there is no evidence to support their effectiveness or to indicate the true extent of the problem. Findings indicate a significant lack of available data to inform health policy. The determinants of health might provide a broad and inclusive framework in which to situate awareness, prevention, early detection, and effective intervention specific to the abuse and neglect of older adults, since economic and social factors contribute to their occurrence.

It is the authors' perspective that enhanced understanding of the causes and consequences of abuse and neglect of older adults will contribute to its eventual elimination. Intergenerational practices that develop from abuse and neglect experiences within families need to be explored: Do they contribute to the experiences, or do they prevent them from developing? Children and youth are part of families, and we observed that clearly missing from the literature was an understanding of young people's experiences with abuse and neglect of older family members, as well as around opportunities to engage them in ways that limit abuse and neglect.

\section{Limitations of this Systematic Review}

The methodology in conducting this systematic review is consistent with others published in recent years. Despite reviewing 13,064 English and French language records and relying on our expert panel to suggest others that we may have missed, the possibility remains that other records related to abuse and neglect of older adults were not identified and reviewed. Although the grey literature, including reporting guidelines, may have provided an alternative means for thinking about abuse and neglect, it was beyond the scope of this systematic literature review.

\section{Conclusion}

Abuse and neglect of older adults is a health and societal problem that occurs across a diverse range of settings and is likely more prevalent than is officially reported. It places a significant burden on older adults, in addition to that which is placed on health care providers, the health care system, and governments. This systematic review identified current evidence on effective approaches for addressing and preventing the abuse and neglect of older adults. However, it is clear that further research is needed to continue to articulate the evidence upon which actions must be taken to address abuse and neglect of older adults.

\section{References}

Almogue, A., Weiss, A., Marcus, E. L., \& Beloosesky, Y. (2010). Attitudes and knowledge of medical and nursing staff toward elder abuse. Archives of Gerontology \& Geriatrics, 51(1), 86-91.

Alt, K. L., Nguyen, A. L., \& Meurer, L. N. (2011). The effectiveness of educational programs to improve recognition and reporting of elder abuse and neglect: A systematic review of the literature. Journal of Elder Abuse \& Neglect, $23,213-233$.

Beaulieu, M., \& Leclerc, N. (2006). Ethical and psychosocial issues raised by the practice in cases of mistreatment of older adults. Journal of Gerontological Social Work, 46, $161-186$

Begley, E., O’Brien, M., Anand, J., Killick, C., \& Taylor, B. (2012). Older people's views of support services in 
response to elder abuse in communities across Ireland. Quality in Ageing $\mathcal{E}$ Older Adults, 13(1), 48-59.

Bond, M. C., \& Butler, K. H. (2013). Elder abuse and neglect: Definition, epidemiology, and approaches to emergency department screening. Clinics in Geriatric Medicine, 29(1), 257-273. doi: 10.1016/j.cger.2012.09.004

Brennan, S. (2009). Victimization of older Canadians. Ottawa, ON: Statistics Canada. Retrieved from http://www.statcan. gc.ca/pub/85-002-x/2012001/article/11627-eng.htm

Buzgova, R., \& Ivanova, K. (2009). Elder abuse and mistreatment in residential settings. Nursing Ethics, 16, 110-126.

Caldwell, H., Gilden, G., \& Mueller, M. (2013). Elder abuse screening instruments in primary care: An integrative review. Clinical Geriatrics, 21(1), 20-25.

Canadian Centre for Justice Statistics. (2002). Family violence in Canada: A statistical profile. Ottawa, ON: Author.

Clancy, M., McDaid, B., O’Neill, D., \& O’Brien, J. G. (2011). National profiling of elder abuse referrals. Age and ageing, 40, 346-352.

Cochrane Public Health. (n.d.). Unit eight: Principles of critical appraisal. Retrieved February 1, 2000 from http://ph. cochrane.org/sites/ph.cochrane.org/files/uploads / Unit_Eight.pdf

Cohen, M. (2011). Screening tools for the identification of elder abuse. Journal of Clinical Outcomes Management, 18(6), 261-270.

Cohen, M., Halevy-Levin, S., Gagin, R., Prilutzky, D., \& Friedman, G. (2010). Elder abuse in long-term care residences and the risk indicators. Ageing $\mathcal{E}$ Society, 30, 1027-1040.

Cohen, M., Levin, S. H., Gagin, R., \& Friedman, G. (2007). Elder abuse: Disparities between older people's disclosure of abuse, evident signs of abuse, and high risk of abuse. Journal of the American Geriatrics Society, 55, 1224-1230.

Cooper, C., Blanchard, M., Selwood, A., Walker, Z., \& Livingston, G. (2010). Family carers' distress and abusive behaviour: Longitudinal study. British Journal of Psychiatry, 196, 480-485.

Cooper, C., Selwood, A., \& Livingston, G. (2009). Knowledge, detection, and reporting of abuse by health and social care professionals: A systematic review. The American Journal of Geriatric Psychiatry, 17, 826-838.

Cripps, D. (2001). Rights focused advocacy and elder abuse. Australasian Journal on Ageing, 20(1), 17-22.

Davies, M., Harries, P., Cairns, D., Stanley, D., Gilhooly, M., Gilhooly, K., et al. (2011). Factors used in the detection of elder financial abuse: A judgement and decision-making study of social workers and their managers. International Social Work, 54, 404-420.

Dow, B., Hempton, C., Cortes-Simonet, E. N., Ellis, K. A., Koch, S. H., Logiudice, D., et al. (2013). Health professionals' and students' perceptions of elder abuse. Australasian Journal on Ageing, 32(1), 48-51.

Fleiss, J. L., Levin, B., Paik, M. C. (2003). Statistical Methods for Rates and Proportions (3rd ed.). Hoboken, NJ: John Wiley \& Sons.

Fulmer, T., Firpo, A., Guadagno, L., Easter, T. M., Kahan, F., \& Paris, B. (2003). Themes from a grounded theory analysis of elder neglect assessment by experts. Gerontologist, 43, 745-752.

Gillespie, L. D., \& Gillespie, W. J. (2003). Finding current evidence: Search strategies and common databases. Clinical Orthopedics and Related Research. 413, 133-145.

Goergen, T. (2004). A multi-method study on elder abuse and neglect in nursing homes. Journal of Adult Protection, 6(3), 15-25.

Harbison, J., Coughlan, S., Karabanow, J., \& VanderPlaat, M. (2005). A clash of cultures: Rural values and service delivery to mistreated and neglected older people in Eastern Canada. Practice, 17, 229-246.

Heath, J. M., Kobylarz, F. A., Brown, M., \& Castano, S. (2005). Interventions from home-based geriatric assessments of adult protective service clients suffering elder mistreatment. Journal of the American Geriatrics Society, 53, 1538-1542.

Hirst, S. P. (2002). Defining resident abuse within the culture of long-term care institutions. Clinical Nursing Research, 11, 267-284.

Hsieh, H. F., Wang, J. J., Yen, M., \& Liu, T. T. (2009). Educational support group in changing caregivers' psychological elder abuse behavior toward caring for institutionalized elders. Advances in Health Sciences Education, 14, 377-386.

Jogerst, G. J., Daly, J. M., Dawson, J. D., Brinig, M. F., \& Schmuch, G. A. (2003). Required elder abuse education for Iowa mandatory reporters. Journal of Elder Abuse $\mathcal{E}$ Neglect, 15(1), 59-73.

Jogerst, G., Daly, J. M., \& Ingram, J. (2001). National elder abuse questionnaire: Summary of adult protective service investigator responses. Journal of Elder Abuse $\mathcal{E}$ Neglect, 13(4), 59-71.

Joubert, L., \& Posenelli, S. (2009). Responding to a "window of opportunity": The detection and management of aged abuse in an acute and subacute health care setting. Social Work in Health Care, 48, 702-714.

Killick, C., \& Taylor, B. J. (2009). Professional decision making on elder abuse: Systematic narrative review. Journal of Elder Abuse E Neglect, 21, 211-238.

Ko, C., \& Koh, C. K. (2012). Factors related to Korean nurses' willingness to report suspected elder abuse. Asian Nursing Research, 6, 115-119.

Koch, S., \& Nay, R. (2003). Reducing abuse of older people with dementia and their carers. Australasian Journal on Ageing, 22, 191-195. 
Lawrence, V., \& Banerjee, S. (2010). Improving care in care homes: A qualitative evaluation of the Croydon care home support team. Aging \& Mental Health, 14, 416-424.

Lindbloom, E. J., Brandt, J., Hough, L. D., \& Meadows, S. E. (2007). Elder mistreatment in the nursing home: A systematic review. Journal of the American Medical Directors Association, 8, 610-616.

Lithwick, M., Beaulieu, M., Gravel, S., \& Straka, S. M. (2000). The mistreatment of older adults: Perpetrator-victim relationships and interventions. Journal of Elder Abuse $\mathcal{E}$ Neglect, 11(4), 95-112.

Long, A. F., Godfrey, M., Randall, T., Brettle, A., \& Grant, M. J. (2002). HCPRDU Evaluation tool for mixed methods. Leeds, England: University of Leeds, Nuffield Institute for Health. Retrieved from http:/ / usir.salford.ac.uk/13070/

McDonald, L., Beaulieu, M., et al. (2012). Defining and measuring elder abuse and neglect. Synthesis of preparatory work required to measure the prevalence of abuse and neglect of older adults in Canada. Ottawa, ON: Human Resources and Social Development Canada (HRSDC).

Malmedal, W., Hammervold, R., \& Saveman, B. -I. (2009). To report or not report? Attitudes held by Norwegian nursing home staff on reporting inadequate care carried out by colleagues. Scandinavian Journal of Public Health, 37, 744-750.

McCool, J. J., Jogerst, G. J., Daly, J. M., \& Xu, Y. (2009). Multidisciplinary reports of nursing home mistreatment. Journal of the American Medical Directors Association, 10, 174-180.

Meeks-Sjostrom, D. J. (2013). Clinical decision making of nurses regarding elder abuse. Journal of Elder Abuse $\mathcal{E}$ Neglect, $25,149-161$.

Mills, W. L., Roush, R. E., Moye, J., Kunik, M. E., Wilson, N. L., Taffet, G. E., et al. (2012). An educational program to assist clinicians in identifying elder investment fraud and financial exploitation. Gerontology \& Geriatrics Education, 33, 351-363.

Moher, D., Liberati, A., Tetzlaff, J., Altman, D. G., \& The PRISMA Group. (2009). Preferred reporting items for systematic reviews and meta-analyses: The PRISMA statement. British Medical Journal, 339, b2535. doi: 10.1136/bmj.b2535

Mosqueda, L., Burnight, K., Liao, S., \& Kemp, B. (2004). Advancing the field of elder mistreatment: A new model for integration of social and medical services. The Gerontologist. 44, 703-708.

Murphy, K., Waa, S., Jaffer, H., Sauter, A., \& Chan, A. (2013). A literature review of findings in physical elder abuse. Canadian Association of Radiologists Journal, 64(1), 10-14.

Nahmiash, D., \& Reis, M. (2000). Most successful intervention strategies for abused older adults. Journal of Elder Abuse E Neglect, 12(3/4), 53-70.

National Seniors Council of Canada. (2007). Report of the National Seniors Council on Elder Abuse. Retrieved from http:/ / www.seniorscouncil.gc.ca/eng/research publications/elder_abuse/2007/hs4_38/page00.shtml Ottawa, ON: Government of Canada.

Perez-Carceles, M. D., Rubio, L., Pereniguez, J. E., Perez-Flores, D., Osuna, E., \& Luna, A. (2009). Suspicion of elder abuse in south eastern Spain: The extent and risk factors. Archives of Gerontology and Geriatrics, 49(1), 132-137.

Phillips, L. R., \& Ziminski, C. (2012). The public health nursing role in elder neglect in assisted living facilities. Public Health Nursing, 29, 499-509.

Ploeg, J., Fear, J., Hutchison, B., MacMillan, H., \& Bolan, G. (2009). A systematic review of interventions for elder abuse. Journal of Elder Abuse E Neglect, 21, 187-210.

Podnieks, E., Anetzberger, G. J., Wilson, S. J., Teaster, P. B., \& Wangmo, T. (2010). WorldView environmental scan on elder abuse. Journal of Elder Abuse E Neglect, 22, 164-179.

Podnieks, E., Pillemer, K., Nicholson, J. P., Shillington, T., \& Frizze, A. (1990). National survey on abuse of the elderly in Canada: The Ryerson Study. Toronto, ON: Ryerson Polytechnical Institute.

Polkastro, C., \& Payne, B. K. (2014). Assessing the level of elder abuse knowledge preprofessionals possess: Implications for the further development of university curriculum. Journal of Elder Abuse E Neglect, 26(1), 2-30.

Pottie-Bunge, V. (2000). Abuse of older adults by family members. In V. Pottie-Bunge, \& D. Locke (Eds.). Family violence in Canada: A statistical profile (pp. 27-30). Ottawa, ON: Statistics Canada.

Proehl, R. A. (2012). Protecting our elders: An interfaith coalition to address elder abuse. Journal of Religion, Spirituality \& Aging, 24, 249-266.

Reay, A. M. C., \& Browne, K. D. (2002). The effectiveness of psychological interventions with individuals who physically abuse or neglect their elderly dependents. Journal of Interpersonal Violence, 17(4), 416-431.

Richardson, B., Kitchen, G., \& Livingston, G. (2002). The effect of education on knowledge and management of elder abuse: A randomized controlled trial. Age and Ageing, 31, 335-341.

Rodriguez, M. A., Wallace, S. P., Woolf, N. H., \& Mangione, C. M. (2006). Mandatory reporting of elder abuse: Between a rock and a hard place. Annals of Family Medicine, 4, 403-409.

Saliga, S., Adamowicz, C., Logue, A., \& Smith, K. (2004). Physical therapists' knowledge of physical elder abusesigns, symptoms, laws, and facility protocols. Journal of Geriatric Physical Therapy, 27(1), 3-10.

Sandmoe, A. (2007). How well can standardized instruments help nurses to identify abuse of older people? A literature review. Nordic Journal of Nursing Research \& Clinical Studies, 27(2), 4-8. 
Sandmoe, A., \& Kirkevold, M. (2013). Identifying and handling abused older clients in community care: The perspectives of nurse managers. International Journal of Older People Nursing, 8, 83-92.

Sandmoe, A., Kirkevold, M., \& Ballantyne, A. (2011). Challenges in handling elder abuse in community care. An exploratory study among nurses and care coordinators in Norway and Australia. Journal of Clinical Nursing, 20, 3351-3363.

Schmeidel, A. N., Daly, J. M., Rosenbaum, M. E., Schmuch, G. A., \& Jogerst, G. J. (2012). Health care professionals' perspectives on barriers to elder abuse detection and reporting in primary care settings. Journal of Elder Abuse $\mathcal{E}$ Neglect, 24(1), 17-36.

Selwood, A., Cooper, C., Owens, C., Blanchard, M., \& Livingston, G. (2009). What would help me stop abusing? The family carer's perspective. International Psychogeriatrics, 21, 309-313.

Shinan-Altman, S., \& Cohen, M. (2009). Nursing aides' attitudes to elder abuse in nursing homes: The effect of work stressors and burnout. Gerontologist, 49, 674-684.

Taylor, D. K., Bachuwa, G., Evans, J., \& Jackson-Johnson, V. (2006). Assessing barriers to the identification of elder abuse and neglect: A communitywide survey of primary care physicians. Journal of the National Medical Association, 98, 403-404.

Teaster, P. B., Nerenberg, L., \& Stansbury, K. L. (2003). A national look at elder abuse multidisciplinary teams. Journal of Elder Abuse \& Neglect, 15, 91-107.

Teresi, J. A., Ramirez, M., Ellis, J., Silver, S., Boratgis, G., Kong, J., et al. (2013). A staff intervention targeting resident-to-resident elder mistreatment (R-REM) in longterm care increased staff knowledge, recognition and reporting: Results from a cluster randomized trial. International Journal of Nursing Studies, 50, 644-656.

Tetterton, S., \& Farnsworth, E. (2011). Older women and intimate partner violence: Effective interventions. Journal of Interpersonal Violence, 26, 2929-2942.

United Nations. (2002). Political declaration and Madrid International plan of action on ageing. New York, NY: Author. Retrieved from http://www.un.org/en/events/ pastevents / pdfs / Madrid_plan.pdf
U.S. Preventive Services Task Force. (2013, April). Screening for intimate partner violence and abuse of elderly and vulnerable adults: Recommendation statement. American Family Physician, 87(8). http:/ /www.aafp.org/afp/2013/0415/ od3.html

Vladescu, D., Eveleigh, K., Ploeg, J., \& Patterson, C. (2000). An evaluation of a client-centered case management program for elder abuse. Journal of Elder Abuse E Neglect, 11(4), 5-22.

Wei, G. S., \& Herbers, G. E. (2004). Reporting elder abuse: A medical, legal, and ethical overview. Journal of the American Medical Women's Association, 58, 248-254.

World Health Organization (WHO). (2000a). The Toronto Declaration on the Global prevention of elder abuse. Geneva, Switzerland: World Health Organization. Retrieved from http://www.who.int/ageing/projects/elder_abuse / alc_toronto_declaration_en.pdf

World Health Organization (WHO). (2000b). The world report on violence and health. Geneva, Switzerland: Author. Retrieved from http://www.who.int/violence_injury_ prevention/violence/world_report/en/introduction.pdf

Wiglesworth, A., Austin, R., Corona, M., Schneider, D., Liao, S., Gibbs, L., et al. (2009). Bruising as a marker of physical elder abuse. Journal of the American Geriatrics Society, 57, 1191-1196.

Wiglesworth, A., Mosqueda, L., Burnight, K., Younglove, T., \& Jeske, D. (2006). Findings from an elder abuse forensic center. Gerontologist, 46, 277-283.

Winterstein, T. B. (2012). Nurses' experiences of the encounter with elder neglect. Journal of Nursing Scholarship, 44(1), $55-62$.

Wolf, R. S. (2001). Support groups for older victims of domestic violence. Journal of Women \& Aging, 13(4), 71-83.

Wong, C., \& Marr, S. (2002). Factors influencing health-care professionals in identifying and managing elder abuse: A preliminary report. Geriatrics Today: Journal of the Canadian Geriatrics Society, 5, 34-47.

Zink, T., Jacobson, J., Regan, S., \& Pabst, S. (2004). Hidden victims: The healthcare needs and experiences of older women in abusive relationships. Journal of Women's Health, 13, 898-908. 